\title{
Krim ekstrak Panax ginseng menghambat peningkatan ekspresi MMP-1 dan penurunan jumlah kolagen pada tikus Wistar jantan (Rattus norvegicus) yang dipajan sinar UV-B
}

\author{
${ }^{1}$ Nize Liliana \\ ${ }^{2}$ Anak A. G. P. Wiraguna \\ ${ }^{3}$ Wimpie Pangkahila
}

\author{
${ }^{1}$ Program Pascasarjana Anti-Aging Medicine \\ ${ }^{2}$ Departemen Penyakit Kulit dan kelamin, \\ ${ }^{3}$ Departemen Andrologi dan Seksologi, Fakultas Kedokteran Universitas Udayana \\ Email: dr.niceskinclinic@gmail.com
}

\begin{abstract}
Ultraviolet B (UV-B) is a source of free radicals that accelerates aging process, especially in the skin. Repeated exposures to UV-B rays activate enzymes that degrade collagen and inhibit collagen production by inducing the expression of MMP-1. Panax ginseng, a typical herb commonly used in Asia, has antioxidant properties. This study was aimed to prove that Panax ginseng extract cream could prevent collagen degradation and MMP-1 elevation in UVBexposed Wistar rats (Rattus norvegicus). This was a true experimental study with the posttest only control group design. Subjects were 30 rats (Rattus norvegicus), Wistar strain, male, aged 10-12 weeks, weighing 160-180 g which were divided into 3 groups with 10 rats each: P0 group, without any treatment; P1 group, exposed to UV-B and treated with placebo; and P2 group, exposed to UV-B and treated with Panax ginseng extract cream. After 48 hours of the last radiation for the entire 2 weeks, all rats were anesthetized, and their skin tissues were prepared for histological examination staining with Sirius red. The expresion of MMP-1 and the amount of collagen were observed under 400x magnification of binocular microscopy. The results showed that the average amount of collagen in the $\mathrm{P} 0$ group was $69.38 \pm 3.96 \%$; in the P1 group was $62.79 \pm 3.50 \%$; whereas in the $\mathrm{P} 2$ group was $80.55 \pm 6.41 \%(P<0.01)$. The mean expression of MMP-1 in the P0 group was $15.43 \pm 3.13 \%$; in the group P1 was $27.99 \pm 5.45 \%$; while in the P2 group was $6.16 \pm 2.33 \%(P<0.01)$. Conclusion: Panax ginseng extract cream could prevent MMP-1 elevation and collagen degradation in UVB-exposed Wistar rats.
\end{abstract}

Keywords: Panax ginseng, collagen, MMP-1, UVB

\begin{abstract}
Abstrak: Ultraviolet B (UV-B) merupakan salah satu sumber radikal bebas yang dapat mempercepat proses penuaan, khususnya penuaan pada kulit. Paparan sinar UVB berulang akan mengaktifkan enzim yang mendegradasi kolagen dan menghambat produksi kolagen melalui peningkatan ekspresi MMP-1. Panax ginseng merupakan jenis herbal yang paling sering digunakan di negara Asia dengan efek antioksidan. Penelitian ini bertujuan untuk membuktikan bahwa pemberian krim Panax ginseng dapat menghambat penurunan jumlah kolagen dan peningkatan MMP-1 pada kulit tikus Wistar yang dipajan sinar UV-B. Jenis penelitian ialah eksperimental dengan posttest only control group design. Subjek penelitian ialah 30 ekor tikus galur Wistar (Rattus norvegicus) jantan, berusia 10-12 minggu, dengan berat badan 160-180 gr yang dibagi menjadi 3 kelompok masing-masing berjumlah 10 ekor tikus, yaitu: kelompok P0 sebagai kelompok kontrol tanpa perlakuan; kelompok P1 diberikan pajanan sinar UV-B dengan plasebo; dan kelompok P2 diberikan pajanan sinar UV-B dengan krim Panax ginseng (P2). Setelah 48 jam penyinaran terakhir selama 2 minggu, seluruh tikus dianestesi, kemudian diambil jaringan kulitnya untuk dibuat preparat histologik. Jumlah kolagen dan eskpresi MMP-1 dermis dihitung sebagai data post test. Hasil analisis menunjukkan rerata jumlah kolagen pada kelompok P0 ialah 69,38 $\pm 3,96 \%$; pada kelompok P1 62,79 $\pm 3,50 \%$; dan pada kelompok P2 80,55 $\pm 6,41 \%$ $(\mathrm{p}<0,01)$. Hasil rerata ekspresi MMP-1 pada kelompok P0 ialah 15,43 $\pm 3,13 \%$; pada kelompok P1 27,99 $\pm 5,45 \%$; dan pada kelompok P2 ialah $6,16 \pm 2,33 \%(P<0,01)$. Simpulan: Pemberian krim
\end{abstract}


Panax ginseng menghambat peningkatan ekspresi MMP-1 dan penurunan jumlah kolagen pada kulit tikus Wistar jantan yang dipajan sinar UV-B.

Kata kunci: Panax ginseng, kolagen, MMP-1, UVB

Penuaan adalah proses yang akan dialami oleh setiap mahluk hidup di muka bumi ini yang terjadi secara bertahap pada seluruh organ. Faktor-faktor yang menyebabkan penuaan dapat dikelompokan menjadi faktor intrinsik dan faktor ekstrinsik. Faktor intrinsik merupakan proses penuaaan yang berlangsung secara alamiah yang dapat disebabkan beberapa faktor antara lain: radikal bebas, berkurangnya hormon, glikosilasi, metilasi, apoptosis, menurunnya sistem kekebalan, dan genetik. Faktor ekstrinsik yang utama ialah gaya hidup tidak sehat, kebiasaan yang salah, polusi lingkungan, stres, dan kemiskinan. ${ }^{1}$

Radikal bebas dianggap sebagai penyebab utama dan paling banyak berkontribusi dalam proses penuaan secara menyeluruh. ${ }^{1}$ Sinar Ultra violet yang berasal dari sinar matahari, khususnya sinar ultraviolet B (UV-B) menyebabkan terbentuknya radikal bebas yaitu reactive oxygen species (ROS). Sinar UV-B juga terbukti meningkatkan dregradasi kolagen, karena sinar UV-B dapat menginduksi berbagai matriks metaloproteinase (MMPs) akibat dari ROS yang terbentuk. Sinar UV (ultraviolet) memacu sintesis MMP-1, MMP-3, dan MMP-9 melalui pelepasan tumor necrosis factor-alpha (TNF- $\alpha$ ) oleh keratinosit dan fibroblas, serta menyebabkan penurunan trasforming growth factorbeta $(\text { TGF- } \beta)^{2,3}$

Radiasi UV diketahui secara langsung dan tidak langsung mengganggu integritas matriks ekstrasel dengan cara meningkatkan aktivitas MMP. Pada kulit manusia, MMP-1 merupakan tipe yang paling terpengaruh oleh induksi sinar UV matahari dan bertanggung jawab terhadap degradasi kolagen pada kulit yang mengalami photoaging. ${ }^{4}$ Ditemukan bahwa hanya dengan satu kali terpajan radiasi UV sinar matahari dapat mengganggu jaringan ikat dengan menyebabkan gangguan sintesis kolagen yang hampir lengkap selama 24 jam yang kemudian diikuti dengan pemulihan setelah 48-72 jam. Degradasi kolagen juga terjadi karena peningkatan kadar MMP-1 yang cukup nyata yaitu sekitar 4,4 $\pm 0,2$ kali lipat dibandingkan dengan kulit yang tidak dipajan radiasi $\mathrm{UV}^{4}$

MMP-1 ialah mediator utama terhadap timbulnya degradasi kolagen pada kulit yang mengalami photoaging. Enzim MMP1 kolagenolitik mendegradasi fibril kolagen dan elastin yang penting untuk mempertahankan kekuatan dan elastisitas kulit. Aktivitas MMP-1 di kulit akan meningkat walaupun hanya dengan radiasi UV yang singkat dan menyebabkan timbulnya kerutan pada kulit, yang menjadi tanda photoaging. ${ }^{5}$ Dengan demikian, hambatan terhadap MMP-1 ialah satu cara mencegah kerusakan kulit akibat paparan radiasi UV.

Selain itu radiasi UV menghasilkan $\operatorname{ROS}^{6}$ dan bersama dengan aktivasi berbagai ROS-sensitive signaling pathways selanjutnya akan memengaruhi berbagai macam fungsi selular termasuk menyebabkan fragmentasi kolagen dan sekresi MMP1. ${ }^{5,7}$ Stress oksidatif berpengaruh besar dalam proses photoaging, fotokarsinogenesis, dan juga dalam patogenesis fotodermatosis. ${ }^{8}$

Panax ginseng berefek anti oksidan melalui mekanisme meningkatkan Type-1 procollagen and protein expression, mencegah induksi gen MMP-1, memperpanjang fibrin dari fibrilin-1, meningkatkan ekspresi prokolagen tipe I, menurunkan kadar MMP-1, ${ }^{9}$ berefek anti inflamasi, menghasilkan anti tumor. dan berpotensi terhadap anti-aging. ${ }^{10}$ Terdapat beberapa tipe ginseng tergantung dari metode pembuatannya, yaitu: fresh ginseng, white ginseng, dan red ginseng. Fresh ginseng adalah ginseng yang utuh dan akarnya yang tidak kering. Bila akar ginseng telah kering karena udara disebut white ginseng. Red ginseng adalah ginseng yang di steam $98^{0} \mathrm{C}-100^{\circ} \mathrm{C}$ dengan akar gingseng kering. ${ }^{10}$ 


\section{METODE PENELITIAN}

Jenis penelitian ini ialah eksperimental dengan menggunakan posttest only control group design. Subjek penelitian ialah 30 ekor tikus galur Wistar (Rattus norvegicus), jantan, berumur 10-12 minggu, dengan berat badan 160-180 gr, yang terbagi menjadi 3 kelompok, masing-masing berjumlah 10 ekor tikus. Kelompok P0 ialah kelompok kontrol tanpa perlakuan; kelompok P1 diberikan pajanan sinar UV-B dengan plasebo; dan kelompok P2 diberikan pajanan sinar UV-B dengan krim Panax ginseng. Setelah 48 jam penyinaran terakhir untuk menyingkirkan pengaruh penyinaran akut, semua tikus dianestesi kemudian diambil jaringan kulit punggungnya dengan ukuran $2 \times 2 \mathrm{~cm}$ untuk dilakukan pemeriksaan jumlah kolagen dan kadar MMP-1 sebagai data post test. Hasil penelitian ini kemudian dianalisis dan disajikan menggunakan analisis deskriptif, normalitas data dengan Shapiro-wilk test, homogenitas data dengan Levene's Test, dan uji komparabilitas dengan one way Anova, kemudian dilakukan uji Least Significant Differences test (LSD).

\section{HASIL PENELITIAN DAN BAHASAN}

Jumlah kolagen dermis adalah persentase pixel jaringan kolagen berupa jaringan berwarna merah terang dengan pewarnaan Sirius red dibandingkan dengan pixel seluruh jaringan yang tampak pada foto sediaan histologik. Penilaian dilakukan pada foto dan perhitungan dengan analisis digital menggunakan piranti lunak adobe photoshop CS3 versi-9 (Gambar 1). Jumlah kolagen dihitung sebagai persentase pixel area kolagen yang berwarna merah dibandingkan pixel area seluruh jaringan. ${ }^{11}$

$$
\text { Jumlah kolagen }=\frac{\text { Pixel area kolagen }}{\text { Pixel } \text { area lapangan pandang jaringan }} \times 100 \%
$$

Hasil penelitian menunjukkan rerata jumlah kolagen pada kelompok kontrol tanpa perlakuan (P0) ialah 69,38 $\pm 3,96 \%$; pada kelompok yang diberikan pajanan sinar UV-B dengan plasebo (P1) ialah $62,79 \pm 3,50 \%$; sedangkan pada kelompok yang diberikan pajanan sinar UV-B dengan krim Panax ginseng (P2) ialah $80,55 \pm 6,41 \%(P<0,01)$. Selain itu, rerata ekspresi MMP-1 pada kelompok P0 ialah $15,43 \pm 3,13 \%$; pada kelompok P1 ialah $27,99 \pm 5,45 \%$; sedangkan pada kelompok P2 ialah $6,16 \pm 2,33 \% \quad(P \quad<0,01)$. Uji lanjutan untuk mengetahui perbedaan individual antar kelompok dengan menggunakan LSD test menunjuk-kan bahwa terdapat perbedaan nyata antara kelompok $\mathrm{P} 0$ dengan kelompok lainnya $(P$ $<0,01)$, dan terdapat perbedaan antara kelompok P1 dan P2 $(P<0,01)$ (Tabel 1).

Hasil penelitian ini terkait dengan kandungan senyawa aktif yang terkandung di dalam Panax ginseng. Hasil analisis kandungan senyawa aktif yang dilakukan di Laboratorium Bukit Jimbaran Universitas Udayana menunjukkan bahwa krim ekstrak Panax ginseng mengandung saponin yang diuji dengan metode Mayer, terpenoid yang diuji dengan metode Liebermann, dan juga positif mengandung alkaloid. Analisis juga menunjukkan ekstrak Panax ginseng mengandung flavonoid sebesar 20,86 mg/100gr QE, fenol sebesar 281,35 mg/100gr GAE, tanin sebesar 224,83 $\mathrm{mg} / 100 \mathrm{gr}$ TAE, vitamin C sebesar 1148,82 $\mathrm{mg} / 100 \mathrm{gr}$, dengan kapasitas antioksidan sebesar 161,42 mg/L GAEAC.

Saponin merupakan senyawa dalam bentuk glikosida yang tersebar luas pada tumbuhan tingkat tinggi. Penelitian menunjukkan bahwa pemberian saponin dengan dosis $100 \mathrm{ng}$ /ekor pada tikus yang diinduksi paparan UV-B dapat mencegah kerusakan kolagen, mencegah penurunan ketebalan kulit, menghambat pembentukan kerutan, dan penurunan elastisitas kulit. ${ }^{12}$ 

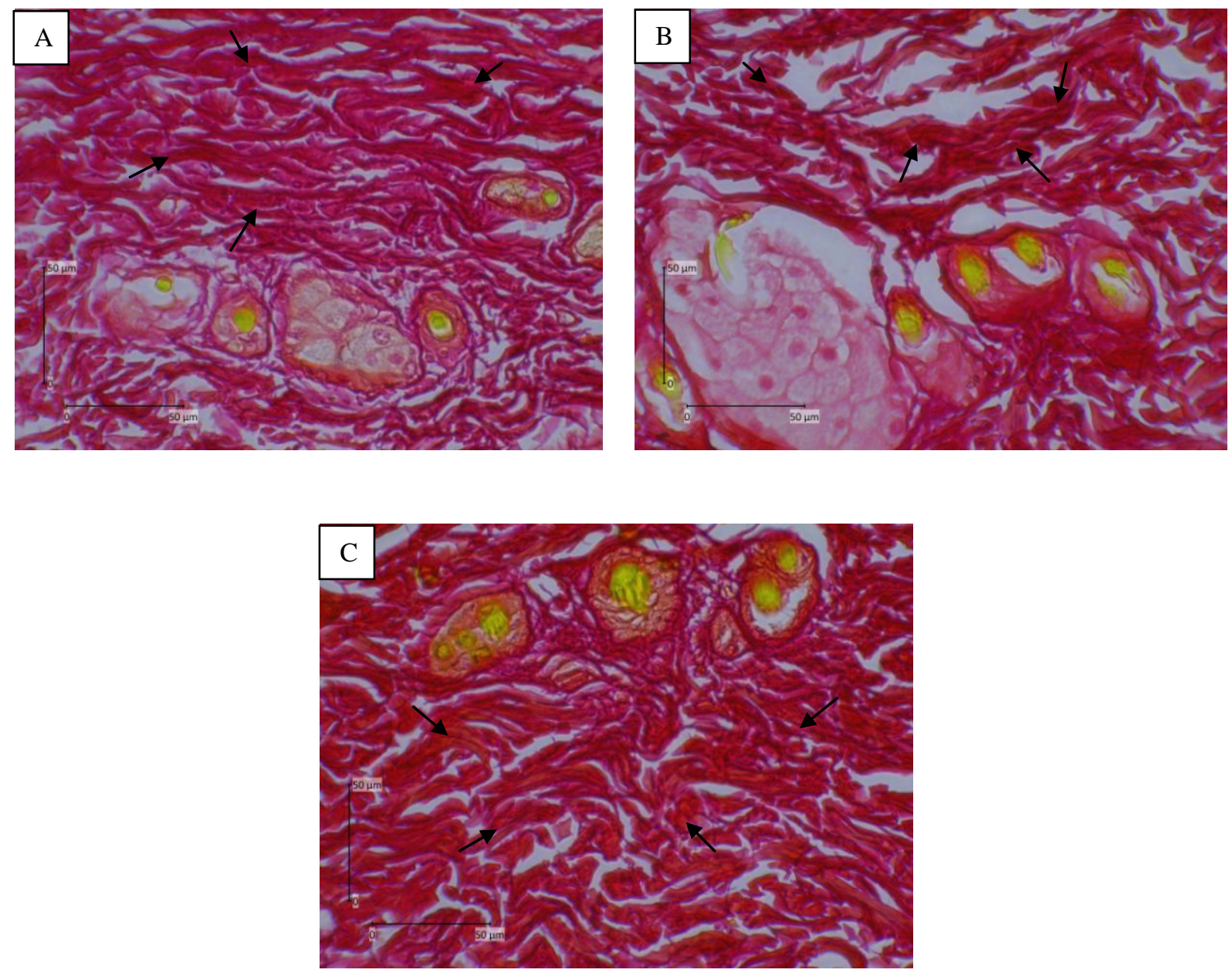

Gambar 1. Histopatologi dermis. A) Kelompok kontrol tanpa perlakuan (P0); B) Kelompok UV-B dan plasebo (P1); C) Kelompok UVB dan krim panax ginseng (P2) (Panah menunjukkan kolagen; Pewarnaan Sirius Red; Pembesaran 400x)

Tabel 1. Rerata jumlah kolagen dan ekspresi MMP-1 antar kelompok

\begin{tabular}{cccccc}
\hline Variabel & Kelompok & n & Rerata (\%) & $\boldsymbol{F}$ & $\boldsymbol{p}$ \\
\hline \multirow{3}{*}{ Jumlah kolagen } & Kelompok P0 & 10 & $69,38 \pm 3,96^{\mathrm{a}}$ & & \\
& Kelompok P1 & 10 & $62,79 \pm 3,50^{\mathrm{b}}$ & 35,012 & 0,000 \\
& Kelompok P2 & 10 & $80,55 \pm 6,41^{\mathrm{c}}$ & & \\
\hline \multirow{3}{*}{ Ekspresi MMP-1 } & Kelompok P0 & 10 & $15,43 \pm 3,13^{\mathrm{a}}$ & & \\
& Kelompok P1 & 10 & $27,99 \pm 5,45^{\mathrm{c}}$ & 80,262 & 0,000 \\
& Kelompok P2 & 10 & $6,16 \pm 2,33^{\mathrm{b}}$ & & \\
\hline
\end{tabular}

*Notasi yang berbeda $(\mathrm{a}, \mathrm{b}, \mathrm{c})$ menunjukkan berbeda bermakna $(P<0,05)$ dengan menggunakan uji Least Significance Difference (LSD)

Penelitian juga membuktikan bahwa asam alpha-hydroxy seperti asam malat dan asam sitrat dapat meningkatkan ketebalan kulit dan kadar glikosaminoglikan dermis pada kulit yang mengalami kerusakan akibat cahaya matahari berlebih. ${ }^{13}$ Selain itu kandungan flavonoid khususnya kandungan morin, rutin, dan chrysin telah terbukti dapat meningkatkan sintesis kolagen pada kultur sel fibroblas manusia. ${ }^{14}$

Vitamin C (asam L-askorbat) adalah antioksidan intrasel dan ekstrasel yang paling penting bagi tubuh. Vitamin $\mathrm{C}$ memberikan banyak manfaat bagi kulit, 
meningkatkan sintesis kolagen dan bersifat fotoprotektor (photoprotector). Vitamin C memiliki aktivitas antiinflamasi yang mendukung aktivitas fotoproteksi-nya. Selain itu vitamin $\mathrm{C}$ terbukti dapat memperbaiki kulit yang telah mengalami photodamage, meningkatkan sintesis kolagen, dan menghambat MMP1 sehingga menurunkan keriput, dan menghambat tirosinase. $^{15}$ Secara garis besar, fungsi vitamin $\mathrm{C}$ topikal pada kulit dapat meningkatkan sstabilitas dan menurunkan sensitivitas kolagen terhadap panas, merangsang pertumbuhan kolagen baik secara in vitro ataupun in vivo, ${ }^{16}$ melindungi kulit dari kerusakan akibat paparan UV melalui aktivitas antioksidannya, serta meningkatkan kepadatan papila dermis melalui mekanisme angiogenesis. ${ }^{17}$ Vitamin $\mathrm{C}$ juga merangsang morfogenesis barier epidermal dan proliferasi fibroblas, membantu sintesis DNA dan metabolism mitokondria, merangsang pembentukan membran plasma, mempercepat penutupan luka, dan mengurangi kontraksi luka. ${ }^{18}$

Ekstrak Panax ginseng mengandung polifenol yang dapat diberikan baik secara oral maupun topikal untuk mendapatkan efek fotoproteksi. Mekanisme antioksidan senyawa polifenol berdasarkan kemampuan mendonorkan atom hidrogen dan kemampuan mengelat ion-ion logam. Setelah mendonorkan satu atom hidrogen, senyawa fenolik menjadi senyawa yang stabil dan tidak mudah mengalami resonansi, sehingga tidak mudah berpartisipasi dalam reaksi radikal yang lain. ${ }^{19,20}$

Ekstrak Panax ginseng juga mengandung flavonoid yang merupakan suatu antoksidan golongan fenol yang banyak ditemukan di sayuran, buahbuahan, kulit pohon, akar, bunga, teh, dan wine. Konstribusi flavonoid untuk sistem pertahanan antioksidan sangat besar. Total asupan harian flavonoid berkisar 50-800 $\mathrm{mg}$, yang lebih tinggi dibandingkan dengan rata-rata asupan harian diet antioksidan lain seperti vitamin C (70 mg), vitamin E (7-10 $\mathrm{mg}$ ) atau keratinoid (2-3 mg). Flavonoid dapat mencegah kerusakan yang disebabkan oleh radikal bebas antara lain dengan memusnahkan radikal bebas secara langsung. Flavonoid dioksidasi oleh radikal dan menghasilkan radikal yang lebih stabil tetapi kurang reaktif. Flavonoid dapat menstabilkan senyawa oksigen reaktif melalui bereaksi dengan susunan reaktif dari radikal tersebut. ${ }^{20}$

Penelitian menunjukkan flavonoid dapat mencegah dan memodifikasi respon untuk menghilangkan radiasi UV-A dan UV-B, meliputi kerusakan oksidatif, formasi dimensiklobutan dimer pirimidin. Ekspresi akut siklooksigenase 2, faktor nuklear B dan translokasi nuklear p56, cfos serta induksi protein p53 dan 8hidroksideoksiguanosin yang menginduksi mutasi gen. Selain itu polifenol pada ekstrak Panax ginseng dapat menstimulasi umur keratinosit untuk memperbaharui sel. Flavonoid juga memengaruhi ketebalan epidermis dengan menstimulasi proliferasi keratinosit epidermis melalui regulasi gen anti-apoptosis seperti bcl-2. Pada hewan coba, flavonoid dapat meningkatkan kandungan karbonil kolagen pada kolagen, yang penting sebagai langkah untuk mencegah penuaan. ${ }^{19}$

Hasil penelitian ini juga menunjukkan bahwa pemberian krim Panax ginseng dapat mencegah peningkatan kadar MMP-1 yang dipicu oleh radiasi sinar UV-B. Panax ginseng yang berasal dari Korea dan Cina telah banyak digunakan sebagai obat tradisional yang berfungsi anti-inflamasi, antioksidan, anti-tumor promoting, dan berpotensi mempunyai efek anti aging. Cho et al. ${ }^{21}$ melaporkan pada hasil studinya bahwa Panax ginseng mempunyai efek pada ekspresi gen dan protein type $I$ procollagen, mencegah induksi MMP-9, menginduksi pemanjangan fibrin pada fibrillin-1, menginduksi ekspresi procollagen type I, dan menurunkan kadar MMP1. Cho et al. ${ }^{21}$ juga melaporkan bahwa proses baru dari ginseng yang dinamakan sun ginseng (SG) yaitu ginseng yang di steaming dengan suhu sangat tinggi untuk meningkatkan the content of less-polar ginsenosides of $R g 3, R g 5$ and $R k l$, sehingga dapat menghasilkan efek terapeutik, juga meningkatkan aktivitas antikarsinogenik, 
aktivitas terhadap radikal bebas, nefroprotektif, dan anti platelet.

\section{SIMPULAN}

Berdasarkan hasil penelitian dapat disimpulkan bahwa krim ekstrak Panax ginseng dapat menghambat penurunan kolagen dan peningkatan MMP-1 pada tikus Wistar yang dipapar sinar UV-B.

\section{DAFTAR PUSTAKA}

1. Pangkahila W. Anti-aging Tetap Muda dan Sehat. Jakarta: Kompas, 2011; p. 15192.

2. Alam M, Havey J. Photoaging. In: Draelos, ZD, editor. Cosmetic Dermatology Products \& Procedures (1st ed). United Kingdom: Blackwell, 2010; p. 3-21.

3. Krutmann J. Skin aging. In: Krutmann J, Humbert $P$, editors. Nutrition for Healthy Skin. New York: Springer, 2011; p. 15-24.

4. Fisher GJ, Wang ZQ, Datta SC, Varani J, Kang S. Pathophysiology of premature skin aging. N Eng J Med. 2001;33:1419-29.

5. Yaar M, Gilchrest BA. Aging of skin. In: Feedberg IM, Eisen AZ, Wolff K, Austen KF, Goldsmith LA, Katz SI, editors. Fitzpatrick's Dermatology in General Medicine (6th ed). Newyork: McGraw-Hill, 2008; p. 963-75.

6. Yaar M. Clinical and histological features of intrinsic versus extrinsic skin aging. In: Gilchrest BA, Krutmann J, editors. Skin Aging (ISBN: 978-3-540-244431. Springer, 2006: p. 10-21.

7. Helfrich YR, Sachs DL, Voorhees JJ. The biology of skin ageing. European Dermatology, 2009; p. 39-42.

8. Stahl W, Heinrich U, Wiseman S, Eichler O, Sies H, Tronnier H. Dietary tomato paste protects against ultraviolet light-induced erythema in humans. J Nutr. 2001;131:1449-51.

9. Cho S, Won CH, Lee DH, Lee MJ, Lee S, So SH, et al. Red ginseng root extract mixed with Torilus fructose and Corni fructose improves facial wrinkles and increases type I pro collagen synthesis in human skin: a randomized, doubleblind, placebo-controlled study. J Med Food. 2009;12:1252-9.
10. Kim WY, Kim JM, Han SB, Lee SK, Kim ND, Park MK, et al. Steaming of ginseng at high temperature enhances biological activity. J Nat prod. 2000; 63(12):1702-4.

11. Kiernan JA. 2011. Sirirus red staining protocol for collagen. Available from: http://www.ihcworld.com/protocol/spe cial_stains/sirius_red.htm. Accessed July 15, 2014.

12. Kim YG, Sumiyoshi M, Sakanaka M, Kimura Y. Effects of ginseng saponins isolated from red ginseng on ultraviolet B-induced skin aging in hairless mice. Eur J Pharmacol. 2009; 602(1):148-56.

13. Kornhauser A, Coelho SG, Hearing VJ. Applications of hydroxy acids: classification, mechanisms, and photoactivity. CCID. 2010;3:135-42.

14. Stipcevic T, Piljac J, Vanden-Berghe D. Effect of different flavonoids on collagen synthesis in human fibroblasts. Plant Foods Hum Nutr. 2006;61(1):29-34.

15. Korać RR, Khambholja KM. Potential of herbs in skin protection from ultraviolet radiation. Pharmacogn Rev. 2011;5(10):164-73.

16. Humbert PG, Haftek M, Creidi P, Lapiere C, Nurgens B, Ricarcard A. Topical ascorbic acid on photoaged skin: Clinical, topographycal and ultrastructural evaluation; double blind study vs placebo. Exp Dermatol. 2003;12:237-44.

17. Sauermann K, Jaspers S, Koop U, Wenck H. Topically applied vitamin C increases the density of dermal papillae in aged human skin. BMC Dermatol. 2004;4(1):13.

18. Boyce ST, Supp AP, Swope VB, Warden GD. Vitamin $C$ regulates keratinocyte viability, epidermal barrier, and basement membrane in vitro, and reduces wound contraction after grafting of cultured skin substitutes. J Invest Dermatol. 2002;118(4):565-72.

19. Chiu AE, Chan JL, Kern DG, Kohler S, Rehmus WE, Kimball AB. Doubleblinded, placebo-controlled trial of green tea extracts in the clinical and histologic appearance of photoaging skin. Dermatol Surg. 2005;31:855-9.

20. Muchtadi D. Antioksidan dan Kiat Sehat di 
Usia Produktif. Bandung: Alfabeta, 2013.

21. Cho EJ, Pioa KL, Jang MH, Baek SH, Kim HY, Kang KS, et al. The effect of steaming on the free amino acid contents and antioxidant activity of Panax ginseng. Food Chem. 2008;107(2):876-82. 